\title{
0.045\% DAC N-055 a choice for poor Afghan surgical patients?
}

\author{
KW Stahl $1^{*}$, H Darmangar ${ }^{2}$ \\ From International Conference on Prevention \& Infection Control (ICPIC 2011) \\ Geneva, Switzerland. 29 June - 2 July 2011
}

\section{Introduction / objectives}

$\mathrm{O}_{2}$ enriched pharmaceutical chlorite $\left[\mathrm{NaClO}_{2}\right.$ German Drug Codex monograph DAC N-055, 1990] contains $\mathrm{Na}_{2} \mathrm{Cl}_{2} \mathrm{O}_{6}$ formerly called TCDO, $\left(\mathrm{NaClO}_{2}\right)_{4} \cdot \mathrm{O}_{2}$ fights tissue infections and promotes wound granulation of radiogenic ulcers [http://www-pub.iaea.org/mtcd/publications/pdf/te_1300_web.pdf]. Under our hygienic conditions the intra- and postoperative topical use of 0.045\% DAC N-055 helps us to deal with bone \& tissue infections in orthopaedic surgery in Mazar. Here we document 4 cases out of the total number of 26 patients, we monitored in the former Military Hospital in Mazar 2004 - 2006 to familiarize ourselves with this German drug first registered as Oxoferin ${ }^{\circledR}$ in 1983.

\section{Methods}

The speed of $\mathrm{ClO}_{2}$ release from $0.045 \%$ DAC N-055 (max. $160 \mathrm{ppm}$ ) increases with decreasing $\mathrm{pH} \cdot \mathrm{ClO}_{2}$ induces no resistance. In all patients the field of surgical intervention is rinsed several times with 0.045 \% DAC $\mathrm{N}-055$ in saline especially during the operation, especially before wound closure and dressed with cotton gauzes kept moist till the patient is discharged home. Post-OP irrigations are practised with $0.045 \%$ DAC N055 for septic arthritis (closed method) and osteomylitis (open method).

\section{Results}

$1 / 2$ septic arthritis, osteomyelitis cases and 2/22 osteomyelitis cases are photo-documented. Without antibiotics, septic arthritis had an excellent functional outcome after 6 weeks, the open fracture with skin defect received mesh graft on excellent granulation after 1 month and was completely closed after 3 months. 11/22 osteomyelitis cases could be monitored for 6 to 18

TWaisenmedizin E. V., Freiburg i. Brsg., Germany

Full list of author information is available at the end of the article months, 6 cases relapsed within this time, for $8 / 11$ patients antibiotics were not available.

\section{Conclusion}

If 4.5\% DAC N-055 could be sold in Afghanistan at 50\% of the price of the finished drug Oxoferin ${ }^{\circledR}$ sold in Pakistan this could help poor patients in traumatology.

\section{Disclosure of interest}

None declared.

\section{Author details}

${ }^{1}$ Waisenmedizin E. V., Freiburg i. Brsg., Germany. ${ }^{2}$ Medical Faculty, Balkh University, Mazar-e-Sharif, Afghanistan.

Published: 29 June 2011

doi:10.1186/1753-6561-5-S6-P246

Cite this article as: Stahl and Darmangar: $0.045 \%$ DAC N-055 a choice for poor Afghan surgical patients? BMC Proceedings 2011 5(Suppl 6):P246.

Submit your next manuscript to BioMed Central and take full advantage of:

- Convenient online submission

- Thorough peer review

- No space constraints or color figure charges

- Immediate publication on acceptance

- Inclusion in PubMed, CAS, Scopus and Google Scholar

- Research which is freely available for redistribution 